\title{
CROP PLANNING AND STUDY OF HYDROLOGICAL CHARACTERISTICS OF 18E/17 WATERSHED OF KANDHAMAL DISTRICT OF ODISHA, INDIA
}

\author{
S. Pattnaik*, R.Subudhi*\& C R Subudhi** \\ *Student, CAET, OUAT, Bhubaneswar \\ **Professor, Dept. of SWCE, CAET, OUAT, Bhubaneswar, Odisha, India
}

\begin{abstract}
This experiment was conducted at Dept.of Soil and Water Conservation and Engineering, CAET, OUAT, Bubaneswar, Odisha, India. It was conducted to estimate the hydrologic parameters of 18E/17 watershed of Kandhamal district under North- eastern ghat zone. In this study the various hydrological parameters of $18 \mathrm{E} / 17$ watershed of Kandhamal district was found out using the topo sheet. To carry out this experiment the contour lines were marked to demarcate the high points and the delineation of watershed was done with this the stream line was also marked which carry the runoff from the entire catchment area. Various features of hydrological parameters were found out. Simulating these data the runoff volume could be calculated and the possibilities of construction of river valley projects in that area can be obtained. The shape of the watershed is fern shape. Due to narrow catchments the peak flood intensity is reduced since discharges are likely to be distributed over a long period of time. The drainage density $\left(D_{d}\right)$ was found to be $11.73 \mathrm{Km}^{-1}$ which is a high value and indicates that the basin is moderately impermeable and also high bifurcation ratio indicates higher Dd. It is affected by permeability, climate, vegetation, length of stream. The watershed planning and the cropping pattern of the watershed in the command area have been carried out.
\end{abstract}




\section{INTRODUCTION}

The watershed $18 \mathrm{E} / 17$ is coming under Kandhamal district of Odisha. It has light textured well drained upland soils and comes under North Eastern Ghat zone of Odisha. The intermittent dry spell and terminal drought affects the crop productivity in most of the years. About $25 \%$ of the rainfall is lost as runoff. Harvesting of the runoff water in dams will conserve the runoff water as well as minimise the soil loss of the watershed. This dam will increase the cropping intensity of the watershed area as well as increase the profit of the farmers.

Watershed based planning will solve this problem. So hydrological parameters will be helpful for this. Ramser(1927), Ghosh (1959), Chow(1964) Nemec (1973) Subudhi (1985),Subudhi (1995), Strahler (1952) \&Chorley et al (1985) expressed different types of relationship among the hydrological parameters. Drainage morphology is defined as a measurement of linear areal and relief characteristics of any drainage basin (Clarke 1966) Drainage morphometry was first initiated by Horton (1932).

Protection, improvement and rehabilitation of watersheds are of critical importance to achievement overall watershed development goals. This can be possible only after collecting existing data, analysing and identifying major watershed problems and considering management possibilities. Keeping in view the watershed, development and management work has been performed. Generally, the stored water in the dam was not utilised according to the irrigation and water requirement of crops in different seasons. Due to the improper planning the farmers grow only one crop instead of two to three crops. So to solve this problem software developed by Hembram \& Subudhi (2016) was used to calculate water and irrigation requirement of different crops and for every watershed the determination of cropping pattern to increase the cropping intensity of the farmers of this tribal area. So taking into considerations of above problems following objectives were selected:

1. To obtain the different watershed characteristics of watershed.

2. To obtain the cropping pattern in the command area of the dam.

\section{MATERIALS ANDMETHODS}

\section{Description of watershed}

This study was carried out at Dept. of Soil and Water Conservation Engineering, College of Agricultural Engineering and Technology, Odisha University of Agriculture and Technology, Bhubaneswar, Odisha during 2019. The $18 \mathrm{E} / 17$ watershed is in Kandhamal district of Odisha (Fig 1), situated between the longitude of $84^{\circ} 0^{\prime}$ to $84^{\circ} 44^{\prime}$ and latitude $20^{\circ} 15^{\prime} 53^{\prime \prime}$ to $20^{\circ} 16^{\prime}$ ' with a geographical area of $1.125 \mathrm{sq} \mathrm{km}$.

The Kandhamal district is under North eastern ghat zone, with elevation of $300 \mathrm{~m}$ to $1100 \mathrm{~m}$ above mean sea level. The geographical area is $7654 \mathrm{sq} \mathrm{km}$ and forest area of $3624 \mathrm{sq} \mathrm{km}$. It has sub tropical climate characterized by hot and dry summer, cool and humid monsoon and cold and dry winter. The soil type is red late rite, light textured, porous and acidic. The percentage of irrigation done in Kharif and Rabi is 12 and $4.5 \%$ respectively. The monsoon scenario of Phulbani normally starts in the second week of June and its cessation in the second week of October. The total 
rainfall is $1407.4 \mathrm{~mm}$ with number of rainy days as 65 (Table 1). The month of August received highest rainfall as well as highest rainy days.

Table 1 Normal rainfall and rainy days at Kandhamal

\begin{tabular}{|l|l|l|l|}
\hline Sl.No. & Month & Monthly normal & $\begin{array}{l}\text { Normal rainy } \\
\text { days }\end{array}$ \\
\hline 1 & January & 9.5 & 1 \\
\hline 2 & February & 14.2 & 1 \\
\hline 3 & March & 20.1 & 1 \\
\hline 4 & April & 31 & 2 \\
\hline 5 & May & 57.3 & 3 \\
\hline 6 & June & 188.7 & 9 \\
\hline 7 & July & 350.4 & 15 \\
\hline 8 & August & 383.2 & 15 \\
\hline 9 & September & 228.2 & 11 \\
\hline 10 & October & 95.7 & 5 \\
\hline 11 & November & 24 & 1 \\
\hline 12 & December & 5 & 1 \\
\hline Total & & 1407.4 & 65 \\
\hline
\end{tabular}

The outlet of the watershed was first marked and then the concentric contour lines were demarcated which shows the high points, joining all the points the delineation of the watershed was done. Delineation is part of the process known as watershed segmentation, i.e., dividing the watershed into discrete land and channel segments to analyze watershed behaviour. This is performed using the tracing paper from the toposheet. The length of run was calculated using a thread and area using graph paper.
Geomorphologic characteristics of the watershed :

The quantitative land form analysis is undertaken for the developed watershed in which flowing water and associated mass gravity movements acting over long periods of time are responsible for development of surface geometry

\section{Linear Aspects of drainage networks Stream Order:}

The stream order represents the degree of stream branching with a watershed. Each length of stream is designated by its order. 


\section{Bifurcation Ratio:}

The bifurcation ratio is defined as the ratio of the number of stream of any order to the number of stream of the next higher order

\section{Stream length:}

The extent of stream length in a watershed reveals the characterises size of various components of drainage network and its contributing surface area.

\section{Stream length ratio:}

Stream length ration $\left(R_{I}\right)$ is defined as the average length of stream of any order to the average length of streams of the next lower order.

\section{Areal Aspects of watershed Total basin area:}

The area $A \cup$ of a basin o order $u$ is the total area projected on a horizontal plane contributing the overland flow to the streams of given order plus all the tributaries of lower order.

\section{Basin Shape:}

The basin shape is the shape of projected surface on thehorizontal planeof basin shape. The basin shape has a significant effect on stream discharge characteristics
The quantitative expression of basin can be characterized by

Form factor, circulatory ratio, elongation ratio

Form factor $\left(\mathbf{R}_{\mathbf{f}}\right)$ : The ratio of basin area to the square of the basin length.

Circulatory Ratio $\left(\boldsymbol{R}_{\mathrm{c}}\right)$ : Circulatory ratio is the ratio of basin area(Au) to the area of the circle having equal perimeter as the perimeter of the drainage basin.

Elongation ratio $\left(\mathbf{R}_{\mathbf{l}}\right)$ : It is the ratio of diameter of a circle having same area as the basin to the maximum basin length.

\section{Drainage Density $\left(D_{d}\right)$ :}

The drainage density is defined as the ratio of the total length of all streams of all orders within a watershed to the total area of the watershed.

\section{Stream frequency:}

It is the number of stream segments per unit area of watershed.

Relief Ratio: It is the ratio of relief (elevation difference between reference points located in the drainage basin) to the horizontal distance on which relief was measured. 

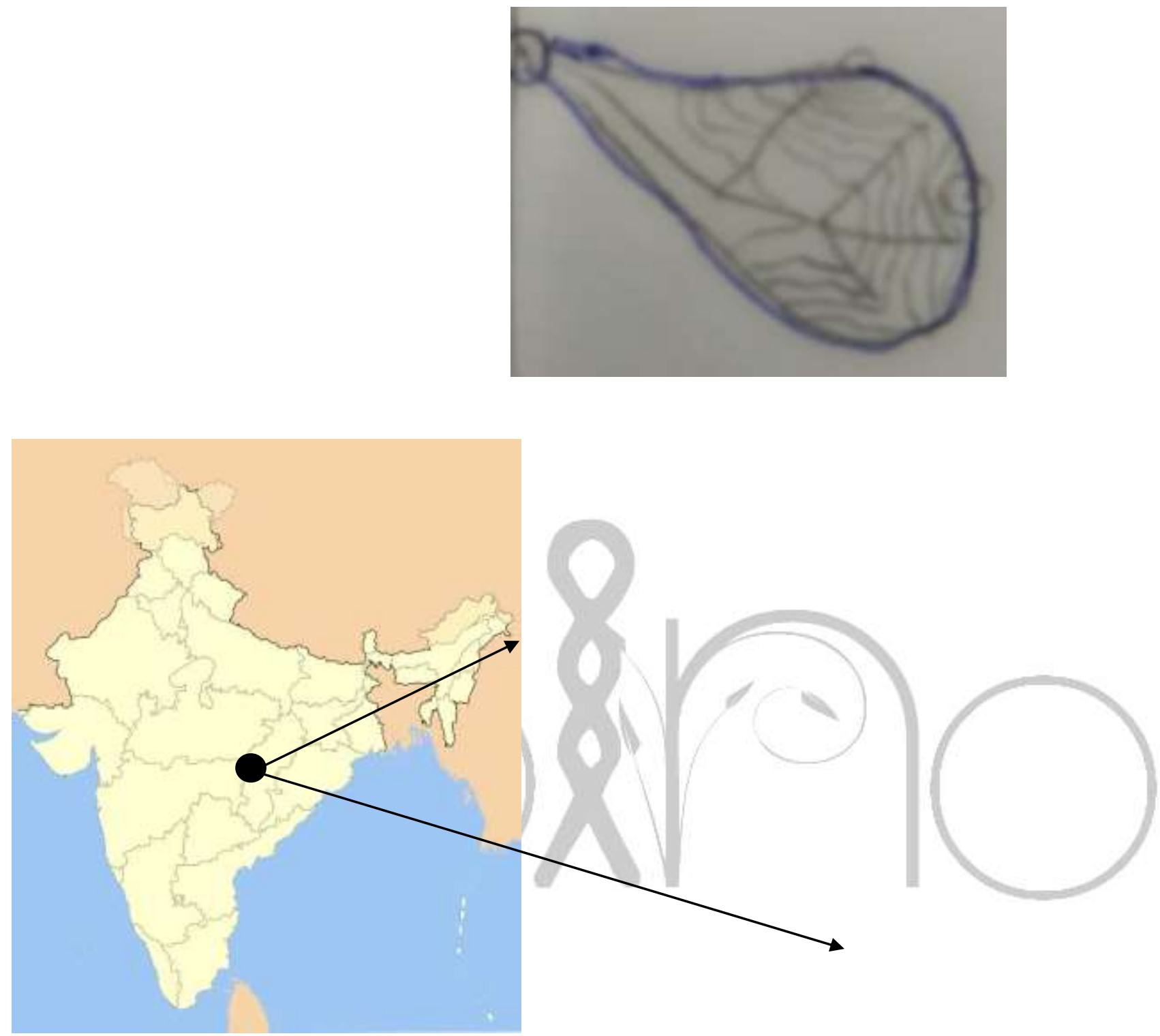

Fig.1 Location map of 18E/17 watershed

The crop water requirement (CWR) and irrigation requirement (IR) of various crops were calculated using a web based software. Relevant crop coefficients (Kc), duration of crops and cropping pattern were used to calculate CWR from ETo. These coefficients present the relationship between references (ETO) and crop evapotranspiration (ET crop) or ET crop = $\mathrm{KC} *$ ETo. The covered area of all crops (canopy cover) was collected. The Kc values were taken from FAO. Crop water and irrigation requirement for majors crops grown in three seasons, summer (rice, sugarcane, sunflower and watermelon), kharif (long duration paddy, medium duration paddy, short duration paddy, banana, mango, maize, brinjal and ladiesfinger) and rabi (green gram, black gram, groundnut, maize, sesamum, mustard, tomato, potato, cabbage and cauliflower) of the all agro2020 November Edition | www.jbino.com | Innovative Association 
climatic zones were calculated. By using the software a farmer can find out the water requirement and irrigation requirement by giving the crop name

\section{RESULT AND DISCUSSION:}

The different linear aspects were presented in Table 2.

Table 2: Linear Aspects of Drainage Networks

\begin{tabular}{|l|l|l|l|}
\hline $\begin{array}{l}\text { Sl } \\
\text { no. }\end{array}$ & Parameters & Abbreviation & Values \\
\hline 1 & Maximum length & $\mathrm{L}$ & $1.4 \mathrm{~km}$ \\
\hline 2 & Maximum width & $\mathrm{W}$ & $0.85 \mathrm{~km}$ \\
\hline 3 & Stream length ratio & $\mathrm{R}_{\mathrm{L}}$ & 0.1 \\
\hline 4 & Stream bifurcation Ratio & $\mathrm{R}_{\mathrm{b}}$ & 4.0 \\
\hline 5 & Mean bifurcation ratio & $\mathrm{R}_{\mathrm{bm}}$ & 4.0 \\
\hline 6 & Length of run & & $1.52 \mathrm{~km}$ \\
\hline 7 & Length of overland flow & $\mathrm{L}_{\mathrm{g}}$ & 0.48 \\
\hline 8 & $\begin{array}{l}\text { Stream length } \\
1^{\text {st }} \text { order }\end{array}$ & $\mathrm{L}_{\mathrm{u}}$ & $13.2 \mathrm{~km}$ \\
$\mathrm{ii}$ & $2^{\text {nd }}$ order & & $1.35 \mathrm{~km}$ \\
\hline 9 & $\begin{array}{l}\text { Mean stream length } \\
\text { i } \\
\text { ii }\end{array}$ & $\mathrm{L}_{\mathrm{sm}}$ & \\
$2^{\text {nd }}$ order & & $3.3 \mathrm{~km}$ \\
\hline
\end{tabular}

The different areal aspects were presented in Table 3 .

Table 3 Areal Aspects of 18 E/17 watershed

\begin{tabular}{|l|l|l|l|}
\hline Slno. & Parameters & Abbreviation & Values \\
\hline 1. & Area & $\mathrm{A}$ & $1.125 \mathrm{~km}^{2}$ \\
\hline 2 & Shape & - & Fern shape \\
\hline 3 & Drainage density A & $\mathrm{D}_{\mathrm{d}}$ & $11.73 \mathrm{Km}^{-1}$ \\
\hline 4 & Stream frequency A & $\mathrm{F}_{\mathrm{s}}$ & $3.55 \mathrm{~km}^{-2}$ \\
\hline 5 & Drainage texture A & $\mathrm{D}_{\mathrm{t}}$ & $1.136 \mathrm{~km}^{-2}$ \\
\hline 6 & Circulatory Ratio A & $\mathrm{R}_{\mathrm{c}}$ & 0.63 \\
\hline 7 & Form Factor A & $\mathrm{R}_{\mathrm{f}}$ & 0.464 \\
\hline 8 & Elongation Ratio A & $\mathrm{R}_{\mathrm{e}}$ & 0.774 \\
\hline 9 & Compactness coefficient A & $\mathrm{C}_{\mathrm{c}}$ & 0.91 \\
\hline 10 & Length/width ratio & - & 1.78 \\
\hline
\end{tabular}

Relief aspects of drainage basin : Relief Ratio: $\left(R_{h}\right)=0.157$

From the above study we observed that 1.After delineating the watershed the shape of the watershed was found to be fern shaped.

- The tributaries are of different lengths and meet the main stream at regular intervals.

- In these narrow catchments the peak flood intensity is reduced since discharges according to their season and duration of crop Hembram P. \& Subudhi C.R. (2016). 
indicates that the basin is impermeable and also the area is underlain by impermeable rocks.. It is affected by permeability, climate, vegetation, length of stream.

4. Moderate bifurcation ratio (4.0) indicates that the watershed is not flood prone.

4. The higher value of stream frequency i.e.3.55 km-2 indicates that there is a relatively quick removal of surface flow of the runoff in the watershed.

5. The form factor (A/Lb2) i.e.0.464 indicates that the watershed is elongated and has longer duration of flow.

6. The circulatory ratio i.e.0.63 indicates that the shape of watershed is indicating that the area is characterized by high relief, elongated, and permeable surface resulting in greater basin lag times. It is influenced by the length and frequency of streams, geological structures, land use/ land cover, climate and slope of the basin.

7. As the elongation ratio should be between 0.6 to 1.0 .values close to 1 are typically of regions of high relief whereas, that from 0.6 to 0.8 are associated with high relief and steep ground slope. This ratio is found out to be 0.774 , the watershed is considered to be of elongated shape and has high relief.

8. The compactness coefficient was found out to be 0.91 which indicates it has more deviation from the circular nature of watershed and it will have long time of concentration before peak of flow.

Taking into consideration of above factors mentioned above watershed and crop planning will be made in this watershed.

Table 4: Irrigation and water requirement for different crops

\begin{tabular}{|l|l|l|l|l|l|l|}
\cline { 2 - 7 } \multicolumn{2}{l|}{} & Kharif & Rabi & \multicolumn{2}{l|}{ Summer } \\
\hline Crops & $\begin{array}{l}\text { Irrigation } \\
\text { requirement } \\
(\mathrm{mm})\end{array}$ & $\begin{array}{l}\text { Water } \\
\text { Requirement } \\
(\mathrm{mm})\end{array}$ & $\begin{array}{l}\text { Irrigation } \\
\text { requirement } \\
(\mathrm{mm})\end{array}$ & $\begin{array}{l}\text { Water } \\
\text { Requirement } \\
(\mathrm{mm})\end{array}$ & $\begin{array}{l}\text { Irrigation } \\
\text { Requirement } \\
(\mathrm{mm})\end{array}$ & $\begin{array}{l}\text { Water } \\
\text { Requirement } \\
(\mathrm{mm})\end{array}$ \\
\hline Paddy (120days) & 444 & 940 & - & - & - & - \\
\hline $\begin{array}{l}\text { Mustard } \\
\text { days) }\end{array}$ & - & - & 224 & 309 & - & - \\
\hline Tomato & - & - & - & - & 480 & 598 \\
\hline
\end{tabular}

i.The Catchment and command area was found out to be -56.25 ha and 56.25 ha respectively.

ii. The Cropping area in Kharif- 56.25 ha, Rabi $=56.25$ ha, Summer $=1.00$ ha

So, the cropping pattern was planned as Paddy, Mustard, Tomato in kharif, rabi and summer seasons respectively according to the amount of rainfall the watershed receives every year. The water and irrigation requirement which was used by using software was shown in Table 4.

\section{Conclusion}

1. The shape of the watershed is fern shape. Due to narrow catchments the peak flood intensity is reduced since discharges are likely to be distributed over a long period of time.

2. The drainage density $\left(D_{d}\right)$ was found to be $11.73 \mathrm{Km}^{-1}$ which is a high value and indicates that the basin is moderately impermeable and also high bifurcation ratio indicates higher Dd. It is affected by 
permeability, climate, vegetation, length of stream. The drainage texture 1.136 indicates that the watershed has coarse texture and has large basin lag time periods.

3. The relief ratio is used as the erosion intensity analysis; here the relief ratio $(0.157)$ indicates that the watershed is less susceptible to erosion.

4. The overland flow of the stream $(0.48$ $\mathrm{km}$ ) indicates that there is gentle slope with longer flow paths.

5. The form factor (0.434) indicating elongated shape and suggesting flat hydrograph peak for longer duration. Flood flows of such elongated basins are easier to manage than those of the circular basin.

6. The compactness coefficient (0.91) indicates that the watershed behaves as a circular basin.

7. The cropping pattern was planned as Paddy, Mustard, Tomato in kharif, rabi and summer.

\section{REFERENCES}

Chorley, R.J. Schumm, S.A.Sugden, D.E. (1985) Geomorphology Methew and Co., Ltd. , London.

Chow, V.T.(1964) Handbook of applied hydrology, a compendium of water resources technology Mc Graw Hill Book Company, New York.
Clarke, J.J. (1966). Morphometrry from map. Essays in geomorphology. Elsevier, New York, pp 235-274.

Ghosh, B.N.(1959) Food estimation J.Inst.Engr.(India), 40(1):391-393.

\section{Hembram P. \& Subudhi, C.R.(2016)} Development of a software for water and irrigation requirement for major crops of north central plateau zone of odisha, Unpublished M.Tech thesis, CAET, OUAT, Bhubaneswar.

Horton R.E. (1945) Erosional development of streams and their drainage basins: hydro physical approach to quantitative morphology. Bull Geol Soc Am 56:275-370.

Nemec, J.(1973) Basic hydrological concepts, Engineering hydrology Tata MC Graw Hill Book Company, New York.

8.Ramser, C.C.(1927) Runoff from small agricultural areas. J.Agri.Res.34(9):797823.

Strahler AN (1964)Quantitative geomorphology of basins \& channel networks In. Chow V.T. (ed) Handbook of applied hydrology. Mc Graw Hill book company, New York.

Subudhi, C.R. (1984) Hydrological event analysis in upper Damodar valley. Unpublished M.Tech Thesis, I.I.T., Kharagpur.

Subudhi; C.R. (1995) Indian Journal of soil Conservation 23(3): 205-207. 